\title{
FROM RUSSIA WITH LOVE \\ NICOLAS NOTOVITCH, NICHOLAS ROERICH, AND THE MYTH OF JESUS IN INDIA
}

\author{
PIOTR KLAFKOWSKI \\ University of Szczecin \\ Institute of Sociology \\ Ethnology and Cultural Anthropology Unit \\ Krakowska 71/79, 71-004 Szczecin, Poland \\ e-mail: pklafkowski@gmail.com \\ (received 7.06.2018; accepted 14.10.2018)
}

\begin{abstract}
This paper discusses the myth of Jesus's stay in India and its alleged source, presenting the four main advocates of it and discussing arguments for and against them. It concludes with some remarks on the development of Western channeled literature connected with the myth. It is intended to be the first of two parts, the second one in preparation.
\end{abstract}

\section{Key words}

The Life of Saint Issa, Nicolas Notovitch, Nicholas Roerich, Swami Abhedananda, Elisabeth Caspari, Ghulam Ahmad, Marcel Theroux, channeled literature.

\section{Abstrakt \\ Pozdrowienia z Rosji. Nicolas Notovitch, Nikołaj Roerich i mit Jezusa w Indiach}

Artykuł omawia mit o pobycie Jezusa w Indiach oraz jego rzekome źródło. Przedstawiono czterech głównych zwolenników tej opowieści i przytoczono argumenty za 
i przeciw. W zakończeniu omówiono najważniejsze dzieła zachodniej literatury zwanej „przekazaną” związane z tym mitem. Jest to pierwsza z planowanych części artykułu (druga w przygotowaniu).

\section{Słowa kluczowe}

Żywot św. Issy, Nicolas Notovitch, Nikołaj Roerich, Swami Abhedananda, Elisabeth Caspari, Ghulam Ahmad, Marcel Theroux, literatura „przekazana”.

Elizabeth Clare Prophet in gratiam memoria

Simplicity, beauty and fearlessness - Christ and Buddha spoke of nothing more. Agni Yoga: Leaves of Morya's Garden, Book 2 - Illumination (1925) Verse 2.4.5.

\section{Introductory}

I should begin by explaining the title of this paper, which is of course taken from Ian Fleming's novel of 1957 and its screen version of 1963, the second James Bond 007 movie. I chose it to stress the Russian connection right from the beginning.

Few myths that were born at the crossroads of the West and the East have proven so enduring as the story of the alleged visit of Jesus to India during his so-called "missing years", that is between his age of 12 or 13 and 30. The story was first presented by a shadowy Russian, Nicolas Notovitch ${ }^{1}$, and its arguably greatest supporter and promoter was another Russian, Nicholas Roerich. However, not many people realize that the suggestions of Christianity's Indian origins had probably first been presented by an Englishman, Francis Wilford, and a Frenchman, Louis Jacolliot, and that there are at least two distinct versions of the story connecting Jesus with India, one coming from the West, the other, from the East. More than that, the modern Western mystic literature contains many books giving various accounts of Jesus and his alleged travels to the East, as well as a disclaimer coming from Jesus himself. The similarities between Buddhism and Christianity have also been discussed by scholars of established international reputation, primarily by Hajime Nakamura and Roy C. Amore, whom nobody can accuse of poor scholarship or falling prey to mysticism. The purpose of this paper is to summarize what is known about these stories, list their sources, and leave the reader to make his/her own conclusions.

The paper is based on the sources I have before me. There are many more that I know of from occasional references or stray quotations, but the references on the web are not always accurate and I prefer not to use those I cannot look up myself in

1 This is the established spelling of his name in English and I will use it throughout this paper. His first name may also appear as Nikolai, Nicolas or Nicholas. Roerich had the same first name, strangely enough. 
printed books. The focus of this paper is on Nicholas Roerich, his source - Notovitch, and those who followed the same trail - Swami Abhedananda and Elisabeth Caspari. I will not go into details of the subsequent development of the myth, limiting myself to an annotated list of the relevant works that I have before me. I am leaving out several works I could not consult in any way even though their bibliographic particulars are known to $\mathrm{me}^{2}$.

In the first two cases I have only the printouts of the electronic versions of these papers available on the web, so I cannot refer to the original page numbers.

I fully realize that the subject like this will not be deemed "academic" by many. However, let me inform the Aristarchs that since the publication of Jon Klimo's monumental Channeling, Investigations on Receiving Information from Paranormal Sources (Klimo 1987, second revised edition 1998), the psychic phenomena have been accepted as a scientific - though controversial - field ${ }^{3}$. I have written this paper because I am a Buddhist philologist who can read Tibetan, who has been both to Leh and Hemis as well as to Rozabal, and who openly declares his interest in spiritual matters and channeled literature.

This paper is intended to be the first part of a larger whole. The second part, hopefully to follow next year, will discuss the philosophical and religious references contained in the sources described below, and try to answer various questions connected with them.

I have the honor of dedicating this paper to the memory of Elizabeth Clare Prophet (1939-2009), once known to millions as Guru Ma, a spiritual teacher and a respected scholar in comparative religion, who published a superb volume containing the annotated documentation of the myth (Prophet 1984), and whose teachings continue to inspire people all over the world. She was fondly referred to as Mother by those who respected her - so thank you, Mother, for all I have learnt from you.

\section{Has Christianity originated in India?}

Not many enthusiasts of Notovitch know that his is not the first book attempting at connecting Christianity and India. As far as it is now known, the pioneering works in his field may have been the ones by Francis Wilford (1761-1822), who based his ideas on earlier works by the Jesuit Antonio Monserette, but the acknowledged first place goes to the French scholar Louis Jacolliot (1837-1890). He was a lawyer, a philosopher

\footnotetext{
2 An excellent guide to this literature is Arild Romarheim's book in Norwegian Kristus i Vannemannes Tegn ("Christ in the Aquarius Sign"), Oslo: Credo,1988, particularly the extensive biblioghraphy pp. 181-190. A shorter version of this book in English is available on the web, titled Various views of Jesus Christ in new religious movements - a typological outline (access 1.07.2018). Rommarheim's book leaves out two important works, the OAHSPE of 1882, and The Urantia Book of 1955. Three major works of this kind postdate Rommarheim's book - The Kolbrin of 1994, The Gospel of the Kailedy of 1998, and Das ist Mein Wort of 2003 (as far as I know, not yet available in English). I am not including the well-known A Course in Miracles (1976, second revised edition 1996) because it does not touch the question of Jesus' alleged travels.

3 I acknowledge my gratitude to Ms. Leslee Alexander for a copy of Klimo's book.
} 
and a translator from the Sanskrit. He was a prolific writer, as evidenced by the long list of his works given in Wikipedia ${ }^{4}$. In his book of 1869 titled La Bible dans l'Inde: Vie de Iezeus Christna, translated into English in $1870^{5}$, he argued that the Biblical accounts of the life of Jesus are too similar to the stories of the life of Krishna to be coincidental. He connected the names of Krishna and Christ, claiming that "Jesus Christ" is in reality the Sanskrit name "Iezeus Christna". However, he stopped short of claiming that Jesus visited India, limiting himself to suggesting that the founding myth of Christianity is an echo of much older Indian traditions ${ }^{6}$. Jacolliot's book is easily available both in various reprints and online $e^{7}$. Another of Jacolliot's books, with an intriguing title Christna et le Christ, 1876, is not available online, though there are reprints.

Let us note that Jacolliot derived Christianity from the traditions of Krishna, that means Hinduism, while the similar claims to follow focused on Buddhism and the similarities between the Buddha and Christ ${ }^{8}$. It is interesting that most of such works appeared within a few years of each other, as the following list (not claimed to be complete) shows:

Nicholas Notovitch - La vie inconnue de Jesus Christ, 1894;

The Unknown Life of Jesus Christ, 1894.

Gideon Jasper Ouseley - The Gospel of the Holy Twelve', serialized 1898-1901, book edition 1901.

Qadiani Mirza Ghulam Ahmad - Jesus in India: series of papers in Urdu 1899, book in Urdu 1908, English translation 1908 (?) $)^{10}$.

Levi (= L. H. Dowling) - Aquarian Gospel of Jesus the Christ, 1908.

Swami Abhedananda - Journey into Kashmir and Tibet (in Bengali) ${ }^{11}, 1922$.

Nicholas Roerich - Altai-Himalaya, 1929;

- Heart of Asia, 1930;

- Himalaya, $1926^{12}$.

4 Louis Jacolliot. Wikipedia (access 23.08.2018).

5 There are numerous reprints of it available from too many publishers to list them here.

6 Francis Wilford stressed the similarities between Indian myths and Christianity, and even claimed that ancient India had her own crucified savior, but I have no access to any of his books and can rely only on his biography and a brief summary of his theories in Wikipedia (access 5.08.2018).

7 www. Mindserpant.com/American_History/books/1870_jacolliot_the_bible_in_india_hindoo_ origin_of_hebrew_and_christian-revelation.pdf (access 5.08.2018).

8 Both reappear in Kersey Graves's well-known book The World's Sixteen Crucified Saviors. A much more balanced and academic presentation of these similarities is given by Hajime Nakamura in his Buddhism in Comparative Light, Delhi: Motilal Banarsidass, 1986.

9 This text is also known as The Gospel of Jesus and The Gospel of Perfect Life.

10 Different sources on Mirza Ghulam Ahmad give either the year 1908 or 1944 for the book edition of his series of papers, but do not make it clear whether it refers to the Urdu or English editions.

11 The English translation of relevant passages is in Prophet 1984.

12 Prophet (1984, p. 257) refers to this book as a monograph published In 1926 from portions of his diary mailed home. However, the official catalogue of Roerich's writings has no such title for 1926. It seems obvious that the book in question is Himalaya: a monograph by Nicholas Roerich, Frances R. Grant, Mary Siegrist, Georgii Grebenshchikov, and Ivan Narodny (New York, Brentano's 1926, limited edition of 500 copies). Most unfortunately, I have no access to it, but I trust Prophet 1984a 
As sometimes there are differences between the same works by Roerich in Russian and English, the present paper will only refer to the English editions, leaving aside the Russian-language ones ${ }^{13}$.

In the following pages we shall first have a close look at the "Hemis Four" - Notovitch, Abhedananda, Roerich, and Mrs. Caspari - then briefly examine the texts related to the myth but not to the Hemis Monastery. We shall have a look at two theories trying to explain why such a text might have been forged and whose interests it could serve. At the very end we shall refer to the words of Jesus communicated to the contemporary mystic, Gabriele of Wurzburg.

\section{The Hemis Monastery}

Notovitch claimed to have discovered the alleged account of Jesus in India at the Himis Monastery in Ladakh. This monastery, today usually called Hemis ${ }^{14}$, is described as having existed prior to the 11th century and having been re-established by Senge Namgyal, the King of Ladakh, in 1627. Its popular histories do not explain the reason of this re-establishment, the term suggesting that the monastery stopped functioning sometime earlier. It belongs to the Drugpa (Tib.brug pa) branch of the Kargyudpa (Tib.bka' brgyud pa) school of Tibetan Buddhism. The Kargyudpa school is famous for the attention it gives to the transmission of teachings and keeping the records of it over many generations of monks. Thanks to its famous monastic dance festival, usually in early June, it is one of the most popular tourist attractions of today's Ladakh. Unfortunately, this means that the Hemis of today is very different from the place visited by Notovitch and Roerich.

\section{Nicholas Notovitch}

Nikolai (the Russian for Nicholas) Notovitch is probably remembered today only as the alleged discoverer of the Tibetan Gospel of Jesus, as he called it. It is somewhat surprising that we know so little about him. He was born in a Russian Jewish family in eastern Crimea, possibly in the city of $\mathrm{Kerch}^{15}$, in 1858 . We do not know anything about his studies. He has written several books, mostly in various political subjects, which are rare and hardly available today. Marcel Theroux describes one of them, $L a$ Russe et l'alliance anglaise of 1906, in the following words: "The frontspiece boasts

complete selection of all the relevant passages, since all of Prophet's references I could check proved correct.

13 For example, the Polish translation of Altai-Himalaya (1980), which is introduced as based on a Russian manuscript in possession of Yuri Roerich Quarters-Museum in Moscow, differs In many places from the English edition of the same text.

14 I have heard both names when in Ladakh, though Hemis seemed more popular.

15 This is suggested, though indirectly, by Marcel Theroux In the Times Literary Supplement of January 9, 2018. 
many new, dull-sounding volumes by the same author and several forthcoming works, few of which ever actually appeared" (Theroux, 2018) ${ }^{16}$.

The list of Notovitch's writings, probably incomplete, is given in Appendix I. None of the titles sounds dull to me. Notovitch is described by Andreyev as a Russophile (Andreyev, 2009), and most of the above titles seem to support the claim.

It is known that Notovitch was a longtime resident of Paris, so most of his books are in French. Marcel Theroux gives a lot of space to Notovitch's book Pravda ob evreyakh (The Truth About the Jews, 1889), which he says is his only book in Russian. However, Alexandre Andreyev (2009) claims that Notovitch authored many works in Russian and the list in Appendix 1 quotes the titles Andreyev gives.

Andreyev (2009) says that there is no doubt about Notovitch's travels in Punjab, Kashmir and Ladakh in 1887. He makes a very interesting suggestion that might explain why those travels are so little known. In the spring of 1887 Maharaja Dalip Singh of Punjab came to Moscow asking the Russian government and the Tsar Alexander III for military help in his planned uprising against the British; he even went as far as asking the Tsar to make India a Russian protectorate. Could it somehow be connected with Notovitch's clandestine travels in Northern India? Marcel Theroux quotes the words of Francis Younghusband ${ }^{17}$, who met Notovitch in India in 1887. As Andreyev points out, Ladakh and Kashmir are close to the Russian borders and many Russian military officials visited Little Tibet ${ }^{18}$, while Tibet proper paid for its alleged contacts with Russia in 1904, when the British invaded it. It is well known that Russia was the British obsession at the turn of XIX/XX centuries as the only power strong enough to rival them in Central and Southern Asia. On the other hand, Theroux (2018) mentions the reports by one Donald Mackenzie Wallace, a Russian-speaking British official, who had several meetings with Notovitch in Simla in July 1887 - the year of the event in Hemis - who claims that Notovitch "volunteered his services as a spy for the British government in India". In Wallace's opinion, Notovitch was but a grandiloquent impostor. When they parted, Notovitch said he would be going back to Russia by overland route - and shortly afterwards he claimed to have visited Hemis.

What a material for a movie easily rivaling The da Vinci Code!

The publication of Notovitch's book cost him a trial and a sentence exiling him to Siberia. This is stated by Andreyev (2009) and confirmed by Fader (2003, p. 182). Notovitch could imaginably settle in Paris only after his Siberian sentence was over. Marcel Theroux's book on Notovitch (Theroux, 2017) does not say anything about it, but it is, as the author says, first and most of all a novel, though based on plausible guesses $^{19}$.

\footnotetext{
16 Theroux says he found the book in the London Library, so - if his description of it is correct there does exist a printed list of Notovitch's works.

17 The British military commander of the invasion of Tibet in 1903-1904. He lived 1863-1942.

18 The name frequently given to Ladakh in the XIX century.

19 It is a great pity that Marcel Theroux does not describe his sources in some kind of afterword. As the novel is well-researched and firmly set in the world it convincingly describes, it is difficult to draw the line between fact and fiction when reading it.
} 
All the encyclopedias and biographic dictionaries that mention Notovitch agree that he disappears sometime in or after 1916, which might indicate he was a war correspondent or just a victim of war. However, Marcel Theroux claims he has seen a book signed by Notovitch in January 1939 (Theroux, 2018), following which date, in Theroux's words, "he drops out of history" (Theroux, 2018). If this is genuine, we know nothing about Notovitch's own "missing years" 1916-1939 and afterwards ${ }^{20}$. If he had been born in 1858, as all reference sources agree, he would have been 81 in 1939, which seems possible. His - most probably - brother Osip Notovitch was born in the same city of Kerch in $1857^{21}$ - though Prophet (198, p. 12), mentions the date 1849.

\section{The Unknown Life of Jesus Christ}

Notovitch's most famous book, La vie inconnue de Jesus Christ, first appeared in French in 1894, followed by the English and German translations that same year. The events described in the book took place in 1887. Alexander Andreyev (2009) says that Notovitch was imprisoned for that book in 1895 and was subsequently exiled into Siberia $^{22}$. Even though the Russian translation of the book appeared only in 1910, let us remember that French and German were the languages well known among the Russian intelligentsia and the book may have caused a furore even before it became available in Russian. But if the book was so dangerous that it landed its author in jail and then in Siberia, what does it really say? Let us begin with a summary based on Prophet (1984, pp. 81-221), which is the complete text of the first edition of its English translation ${ }^{23}$.

The book is much more complex than its popular descriptions and capsule summaries indicate. It consists of two parts: the travelogue titled Journey to Thibet (pp. 83-190) and The Life of Saint Issa, Best of the Sons of Man (pp. 191-221). The book opens with three introductory texts:

- Translator's Note by Violet Crispe (pp. 83-88, with a photograph of Notovitch facing p. 83) dated February 1, 1895;

- To the Publishers, a letter by Notovitch (pp. 89-102), undated;

- Preface, by Notovitch (pp. 102-107), undated.

The book includes two maps:

- The Author's Itinerary Across India (facing p. 109);

- The Author's Itinerary Across Kashmir and Ladak ${ }^{24}$ (pp. 146-147).

\footnotetext{
20 Here again we must be sorry Theroux did not say what in his novel is facts, and what is literary fiction.

21 Fader (2003, p. 182) describes Osip as Nicolas's elder brother, but Theroux (2018) says he may have been his cousin.

22 See Fader, 2003, pp. 179-185. He quotes Notovitch's own account of the episode from the revised and enlarged edition of his book published in 1900. Fader, 2003, seems to base his own narration on Klatt (1988). Neither of these is available to me.

23 There was a revised and enlarged edition in 1900, but I have no access to it. See Fader (2003, pp. 181-182).

24 This is the way Notovitch writes the name today spelt „Ladakh”.
} 
The book is illustrated with several drawings and a few photographs ${ }^{25}$.

These introductory texts contain a wealth of references, following which would make this paper much too long. Let us only say that they leave no doubt the author was well-versed in what was then known about Tibet and its Buddhism, as well as in the writings of missionaries to Tibet. Notovitch's letter To the Publishers contains his answer to Max Muller's accusations of forger $y^{26}$ and the explanation why he does not disclose the name of the Roman Cardinal he quotes on p. 105, while he refers by names to Cardinal Rotelli, Jules Simon, and Ernest Renan.

The description of Notovitch's travel through Kashmir and Ladakh leaves no doubt the man had been there. To the undersigned, who covered the same route in 1976, when Ladakh had not yet been invaded by tourists who changed the country irreversibly, Notovitch's descriptions are familiar from personal experience. It is strange, though, to read Notovitch's conversations with the local lamas, who use expressions like "All our efforts are centered in endeavoring to bring back these Mussulman descendants of Buddhists to the way of the true God" (p. 136-137). It sounds too Christian to be true.

It was in the monastery in the village of Wakka ${ }^{27}$, not far from Mulbekh, that Notovitch came to know about Saint Issa (pp. 137-139), but not about the actual location of the book recording his life. This came much later, at Himis ${ }^{28}$, in a long conversation with the chief lama of the monastery (pp. 172-186, the information about The Life of Saint Issa on pp. 185-186). Notovitch was told that the original was in Pali, and it was brought from India to Nepal and subsequently to Tibet, where it was translated into Tibetan ${ }^{29}$. Asking about it, Notovitch uses the word rolls, maybe because of the Chinese context of the question. However, when he actually sees the mysterious book, he describes it as two large bound volumes (p. 188), adding that the text is written in

25 On p. 107 Notovitch explains that his original photographs got destroyed when his servant exposed the negatives to light, and that he got the photographs used as illustrations from his friend M. d'Auvergne. The author of the drawings is not given.

26 Max Muller (Friedrich Max Muller 1823-1900) was probably the greatest Sanskrit scholar of the 19th century. He is too well known to go into the details of his life and works. However, he has raised a point against Notovitch that makes little sense. Max Muller stressed that The Life of Saint Issa is not listed in the catalogues of the Tibetan Buddhist Canon. But should it be there? The first part of the Canon, the Kengyur, contains the texts attributed to the Buddha, and the second, the Tengyur, their commentaries. The Life of Saint Issa does not fall into either category; at best, if genuine, it would be a rnam-thar or biography to the Tibetan reading audience, but certainly not a part of the Canon. Max Muller's articles on Notovitch appeared in the journal The Nineteenth Century (vol. 36 of July-December 1894, pp. 515-522). They are available on the web under the heading: Articles on the Notovitch hoax from The Nineteenth Century magazine (access 1.07.2018).

27 Today spelt Wakha.

28 Today spelt Hemis, but the actual pronunciation comes closer to Notovitch's spelling.

29 From the remarks by Notovitch on the Tibetan language (p. 136) it seems clear he knew at east something about it. It is true that while the pronunciation of the spoken language is relatively easy, the written language and the orthography are very difficult. Maybe it does not need eight characters to represent one sound, as Notovitch says, but for example the Tibetan for eight is brgyad (in Tibetan grammar $\mathrm{Y}$ is considered a consonant) and pronounced "gye". 
isolated verses (does it refer to the graphic way it was written or to the meanings of the verses?). This is definitely unlike Buddhist books, as even the verses of, say, the Dhammapada are complete in themselves and form connected chapters.

And here we come up against something very, very strange. Notovich described the text as bound volumes, which suggests a Western-style book with binding along the spine. However, the text shown at the same Hemis Monastery to Mrs. Caspari in June of 1939 (Prophet 1984, photo facing p. 313 and pp. 317-321) is definitely a Tibetan xylograph. Of course, it is theoretically possible that the text written in "two large bound volumes" could have been "reprinted" in Tibetan style between 1887 and 1939, but why should it be, if the original had been in the monastery for a very long time and its Western form did not disturb anyone?

\section{The Life of Saint Issa}

The text is divided into fourteen chapters of various length, with numbered verses reminding one of the modern editions of the Bible ${ }^{30}$. Let us have a detailed look at it, chapter by chapter.

Chapter I - 5 verses.

A great crime has been committed in Israel, as the great Issa was tortured and put to death. This is related "to us" by the merchants coming from Israel.

Chapter II - 19 verses.

History of the Israelites and Prince Mossa (= Moses), and a remark on the Exodus. Chapter III - 12 verses.

The subsequent history of the Israelites until their subjugation by Rome.

Chapter IV - 13 verses.

The birth of the miraculous child named Issa. At the age of 13, when an Israeli boy should get a wife, Issa leaves home secretly and joins the merchants going to $\operatorname{Sind}^{31}$.

Chapter V - 27 verses.

At his age of fourteen Issa comes "on this side of Sind" (=Hindustan), crosses the country of five rivers ${ }^{32}$ and enters Rajputana where the Jains ask him to join them. He

\footnotetext{
30 We are taking such versification for granted, but it is a relatively new development. Not going into the history of the editing of the Bible, let us remember that the first Hebrew Bible with chapters and verses numbered was prepared by Rabbi Isaac Nathan ben Kalonymus (dates of birth and death unknown) in ca. 1440. Santi Pagini (1470-1541) was the first to divide the New Testament chapters into numbered verses in his edition of the New Testament of 1527 . However, the units were too long, and in 1551 Robert I Etienne (1503-1559) printed the Latin New Testament with verse numbering still in use today. Let us add that Etienne used the classical Vulgate and its new (then) Latin Translation of 1516 by Erasmus.

31 This name needs an explanation. The river we know as the Indus was originally called Sindhu in Sanskrit. In 515 BCE, when Darius of Persia conquered the Indus Valley, the Persians pronounced Sanskrit initial /s/ as /h/, hence the river came to be known as Hind, and the lands behind it, as Hindustan. This reflects one of the features of the Indo-Iranian group of languages. On the other hand, the Greek geographers always referred to the people we call the Hindus as "Indoi", the people of the Indus. The name "Indians" remains ambiguous since Columbus.

32 Punjab, the name meaning „Five Rivers”.
} 
goes on to Juggernaut in Orissa ${ }^{33}$ where the white priests ${ }^{34}$ of Brahma teach him the Vedas $^{35}$. He angers the Brahmanas by staying with the Vaisyas and Sudras, denies the divine origin of the Vedas and the Brahma-Shiva-Vishnu Trinity and gives teachings on these subjects.

Chapter VI - 16 verses.

The priests and warriors decide to have Issa killed. He escapes to the land of the Gautamides, learns the Pali language and is appointed by the Buddha to spread his teaching ${ }^{36}$. He leaves Nepal and goes back to Rajputana, where he gives many teachings.

Chapter VII - 18 verses.

Issa continues his work among the pagans ${ }^{37}$ and gives many teachings.

Chapter VIII - 24 verses.

Issa enters Persia, has a rather heated dispute with the Zoroastrian priests, but is allowed to go on undisturbed.

Chapter IX - 17 verses.

At his age of 29 Issa returns to Israel and gives teachings arguing that the human heart is more important than the temples.

Chapter X - 21 verses.

As Issa continues from town to town, the officials get scared of him and report on him to Pilate, the governor of Jerusalem. He orders that the Hebrew priests and elders should seize Issa and judge him in the temple. The elders question Issa on various points and get his answers.

Chapter XI - 15 verses.

The priests and elders decide to leave Issa in peace, as he means no harm to anyone. Pilate is angry with this and sends his own men to spy on Issa and report every word he says in public.

Chapter XII - 21 verses.

Issa explains his attitude to Cesar and teaches on the necessity of respecting woman. Chapter XIII - 25 verses.

Issa teaches in public for three years, while the governor's agents follow him from place to place. He becomes increasingly popular, so the governor decides to imprison him. He is cruelly tortured in jail. The high priests and the elders appeal to the governor to set him free, which he denies, but agrees to put Issa before the tribunal of the

33 Today's Jagannath In Odisha.

34 This refers to the division of the Indian society into four Varnas. The Sanskrit word Varna means colour, compare the Polish barwa. Each of the Varnas had its own colour: the Brahmanas (priests) white, the Kshatryas (warriors and rulers) - red, the Vaisyas (farmers, artisans, and traders)- yellow, the Sudras (those who willingly serve the previous three) - black. Arguments continue whether these names refer to actual skin complexion or they should be taken allegorically.

35 A questionable point. Would a foreigner be taught to read and understand the Vedas? Very unlikely.

36 Another question mark. The Buddha died ca. 543 BCE, over five centuries before Issa (if he was Jesus) would be born.

37 In the context of ancient India, the word „pagan” is completely out of place, particularly in the Buddhist thinking. 
ancients. He questions Issa and decides he should be put to death by the priests and the elders, but they see no blame in him. Pilate himself orders the execution. The priests and the elders wash their hands off Issa's blood.

Chapter XIV - 11 verses.

Isa and two thieves are crucified. He dies at sunset. Pilate gives his body to his parents for burial. Three days later he orders the body to be buried elsewhere, but the tomb is empty. Pilate prohibits Issa's name to be mentioned, but people keep talking about him and his teachings spread farther and farther. Issa's disciples scatter themselves among the heathen.

This, in a very general summary, is the content of The Life of Saint Issa. Let us remember that the text must have undergone several changes, as it was first translated from Pali into Tibetan, then into (presumably) English when Notovitch took it down, then rewritten and edited in French in its present form, and finally (re?)translated (back?) into English by Violet Crispe.

\section{Swami Abhedananda}

The basic text for the following discussion is to be found in Prophet (1984, pp. 223-237).

The man the world knows as Swami Abhedananda was born Kaliprasad Chandra in Calcutta in 1866 and died in his home city in 1939. He was the last surviving disciple of the famous Shri Ramakrishna (1836-1886), and a friend and associate of Swami Vivekananda (1863-1902). He became a monk on the death of his teacher Ramakrishna and took the name Swami Abhedananda ${ }^{38}$. He was one of the most active propagators of the Vedanta ${ }^{39}$ philosophy in the West, serving various functions in Vedanta societies in London and New York. He was a prolific writer in his native Bengali and English; his collected works in English amount to 11 volumes comprising over thirty separate books.

Abhedananda went to the US in 1897 - the year of publication of Notovitch's book in French and English - and remained there until 1921. It is during that time he came to know Notovitch's book, which must have made a deep impression on him. On his

38 Its approximate meaning is "The Wise One Joyful in Being Not Different from God".

39 Vedanta, literally "the termination of Vedas" is the highest of the traditional Six Systems of classical Indian philosophy. Its basic texts are the Upanishadas. The most famous one-liner (so to say) of Vedanta is the Sanskrit statement "Tat tvam asi" (=You are it/this), that teaches the identity of Man with the Absolute. Another teaching of Vedanta is that there are three aspects or features of everything that is. Called Three Gunas or features: sattva = beauty, purity, calmness, goodness, imperturbability; rajas = emitions, feelings, fears, aggression; and tamas = passivity, ignorance, inertia. The first guna maintains and preserves, the second one activates, sets in motion, and the third one obstructs, hinders, blocks, makes impossible. This immediately associates with Trimurti of the Indian Trinity: Brahma the Creator, Shiva the Destroyer, and Visnhu the Preserver. This Trimurti is what Issa was against, as described in chapter V of The Life of Saint Issa. Vedanta is the core of teachings of The International Society of Krishna Consciousness or the Hare Krishna Movement. The key element of Abedananda's name - bheda - means "difference" and is one of the technical terms of Vedanta. 
return to India in 1921 he decided to go to Hemis and check the story himself. He had a double advantage: he was a native son of India and, at the age of 56, he was a wellknown philosopher and teacher of wisdom, and such were respected all over India.

He described his 1922 journey to Hemis in the book, originally in Bengali, titled Kashmir o Tibbate (Kashmir and Tibet), published in 1929, revised and re-edited in 1954. I assume that this revised edition is the basic text for the translation given by Prophet (1984). I have no access to the original edition, nor to the complete English translation. Prophet (1984, pp. 223-237), was the first translation of Abhedananda's narrative into English, prepared on Elisabeth Clare Prophet's initiative. For obvious reasons it only covers Abhedananda's account of the book on Saint Issa. I have seen references to the complete English edition of Abhedananda's book but not the book itself, so I prefer not to repeat anything that I have seen written about it. The web is not always a reliable source, particularly on controversial topics.

Abhedananda saw The Life of Saint Issa - in his own words, "the manuscript" ${ }^{40}$. The lama told him it was a copy of the original kept at Marbour monastery near Lhasa ${ }^{41}$. According to the lama, the original was in Pali, but it was later translated into Tibetan. This agrees with what Notovitch was told in 1887.

An important editorial comment in Prophet (1984, p. 231) has to be quoted here in full:

In chapter 13 of In Kashmir and Tibet,Swami Abhedananda described his experiences at Himis and reproduced only the portion of the Himis manuscripot covering Jesus's trek to India. He placed the other verses from the Himis manuscript in chapter 15 of his work. We have taken the excerpt from chapter 15 and inserted it into chapter 13 in order to put the verses in their original, and chronological, order. Abhedananda's version of the Himis manuscript almost exactly parallels Notovitch's Life of Saint Issa through chapter 5, verse 4. Following that, Abhedananda excerpted parts of the Himis manuscript corresponding to scattered verses of The Life of Saint Issa through chapter 9 , verse 1 .

Can we check whether Notovitch and Abhedananda were shown the same text, forgetting its physical form? I assume that Abhedananda conversed with the lamas in English (although in his case Hindi or Urdu cannot be excluded), and then translated his notes into Bengali, so the English text may also be different from the original. Let us compare a few stray verses from both texts ${ }^{42}$.

The title, Notovitch 1894: The Life of Saint Issa: Best of the Sons of Men.

\footnotetext{
40 As a large number of Tibetan books are hand-written and hand-copied, this word here only means it was not a print. But there is another point to it. Notovitch saw "two large bound volumes". He was not used to Tibetan rectangular books wrapped in cloth, so had he seen such, he would have most probably noted it. On the other hand, Abhedananda was used to Sanskrit manuscripts, which were often written on oblong sheets of paper very much like Tibetan books, so had HE seen a Western-style bound manuscript in a Tibetan monastery, he would have very likely noted it. This may indicate that each of them saw a different book.

41 Could it mean the central part of the Potala Palace that is called in Tibetan Phobrang Marbo/ The Red Palace (Tib.pho brang dmar po)? Or its location, Marbori (Tib.dmar po ri)/ The Red Mountain? 42 See Trebst (2005, pp. 293-323) for the parallel comparison of the Notovitch text with all the other alleged passages from it and The Aquarian Gospel of Jesus the Christ.
} 
The title, Abhedananda 1929 (?): Jesus Christ, the Leader of Man ${ }^{43}$.

First, direct narrative.

The Life of Saint Issa, Notovitch 1894, chapter I verses 1-2:

$1 /$ The earth had trembled and the heavens have wept because of a great crime which has been committed in the land of Israel.

2/ For they have tortured and there put to death the great and just Issa, in whom dwelt the soul of the universe.

The same, Abhedananda 1929 (?):

$1 /$ The Jews, descendants of Israel, committed such heinous sins that the earth trembled and the gods in heaven wept.

2/ Because they infinitely tortured and killed Issa, the great soul in whom the Divine Soul rested.

Chapter II verses 1-2, Notovitch 1894:

$1 /$ The people of Israel, who dwelt on a fertile soil giving forth two crops a year and who possessed large flocks, excited by their sins the anger of God.

2/ Who inflicted upon them a terrible chastisement in taking from them their land, their cattle, and their possessions. Israel was reduced to slavery by the powerful and rich pharaohs who then reigned I Egypt.

The same, Abhedananda 1929 (?):

$1 /$ The tribes of Israel used to live in a very fertile land which yielded two crops in a year. They had several herds of sheep and goats. By their sinful act, they incurred the wrath of God.

2/ For this reason, God confiscated all their property and placed them into the slavery of the pharaoh, the powerful ruler of Egypt.

Second, a philosophical passage.

The Life of Saint Issa, Notovitch 1894, chapter IV, verses 1-5:

$1 /$ At this time came the moment when the all-merciful Judge elected to become incarnate in a human being.

2/ And the Eternal Spirit, dwelling in a state of complete inaction and of supreme beatitude, awoke and detached itself for an indefinite period from the Eternal Being.

3 / So as to show forth in the guise of humanity the means of self-identification with Divinity and of attaining to eternal felicity.

4/ And to demonstrate by example ho man may attain moral purity and, by separating his soul from its mortal coil, the degree of perfection necessary to enter into the kingdom of heaven, which us unchangeable and where happiness reigns eternal.

5/ Soon after, a marvelous child was born in the land of Israel, God himself speaking by the mouth of this infant of the frailty of the body and the grandeur of the soul.

The same in Abhedananda 1929 (?):

1/ The Supreme God, Father of the Universe, out of great compassion for sinners, desired to appear on earth in human form.

2/ That Incarnation appeared as a soul separate from that Supreme Soul who has no beginning, no end, and is above all consequence.

43 If this is the original title, why each time the hero is mentioned by name in the text Abhedananda quotes, he is called Issa, not Jesus? 
3/ [He] descended to show how a soul an unite with God and realize eternal bliss,

4/ and assumed a human form to demonstrate in his own life how a mortal man can achieve righteousness and separate the soul from the mortal body in order to gain immortality and proceed to that heaven of the Father of the Universe, where there exists eternal bliss.

$5 /[\mathrm{He}]$ appeared as an immaculate child in the land of Israel. The child became the spokesman of the Father of the Universe to explain the transient nature of the body and the glory of the soul.

Reader of the above should remember that there are no capital letters in Pali, Sanskrit, and Tibetan, all letters of the respective scripts being same size. The capital letters in the above renderings reflect the attitudes of the Western translators.

It seems that the two texts agree as far as the main message is concerned, while they show many differences. Some of these may be attributed to different translators and translations, but not all. The philosophical parts in Abhednanda's rendering sometimes sound like distant echoes of Vedanta, while Notovitch's version often reads like King James Bible.

The text given by Abhedananda covers chapter I, verses 1-5; chapter II, verses 1-4 (Notovitch has 19 verses); chapter III is missing; chapter IV verses 1-14 (Notovitch has 13 verses); and chapter $V$, verses $1-4$, and a very brief summary of the text corresponding to Notovitch chapter V verse 3 through chapter IX verse 1. Even allowing differences in wording, the division of the text into verses is sometimes different in the two versions.

\section{Nicholas Roerich}

The basic text discussed below is Prophet (1984, pp. 239-280).

Nicholas Roerich was born in Sankt-Peterburg in 1874 and died in Naggar, India, in 1947. I assume he needs no detailed presentation. For the sake of this paper let it be stressed that both Nicholas and his wife Helena (1879-1955) were deeply believing Theosophists, and that Nicholas was passionately interested in the classical cultures of India and India's cultural links with Russia and the West. The Roerichs lived in India since 1923. In 1925-1928 Nicholas Roerich led the Central Asian Expedition now known as the Roerich expedition. He was the initiator of the international pact for the preservation of cultural monuments in times of war and peace, signed in Washington in 1935 and now known as the Roerich Pact, for which he was nominated to the Nobel Peace Prize. In 1934-35 he led another expedition to Mongolia, Manchuria, and China. His enormous creative output comes to at least 20 volumes of writings of all kinds - there is no complete edition yet - and approximately 7000 paintings and other graphic works mostly with deep symbolic undertones ${ }^{44}$.

Nicholas Roerich was an enthusiast of everything mysterious and mystic, which makes the reading of his books an emotional rather than purely intellectual experience. He has the somewhat distressing habit of suggesting something, but never say-

44 For more about the Roerichs see Gdok-Klafkowska (2011) and Klafkowski (2018) (forthcoming). 
ing anything definite. This is no criticism, for there are few writers who impress their readers the way Roerich does; it is rather to stress that his writings cannot be taken as unassailable academic statements, for the author saw only what he wanted to see and this mostly in black and white.

Prophet 1984 gives a collection of passages from the three relevant books that mention The Life of Saint Issa. Already at the beginning we encounter a typically Roerichian trick:

The writings of the lamas say that Christ was not killed by the Jews but by the representatives of the government... In the documents which have the antiquity of about 1500 years one may read... (Prophet 1984, p. 270)

Is it not obvious that the reader will ask "What writings?" and "What documents?"? However, Roerich is careful not to say a word about it.

Another example:

Regarding the manuscripts of Christ - first there was a complete denial. Of course denial first comes from the circle of missionaries. Then slowly, little by little, are creeping fragmentary reticent details, difficult to obtain. Finally it appears - that about the manuscripts, the old people of Ladakh have heard and know... And such documents as manuscripts about Christ and the Book of Chambhalla ${ }^{45}$ lie in the 'darkest' place. And the figure of the lama - the compiler of the book - stands like an idol in some sort of fantastic headgear. And how many other relics perished in dusty corners? For the tantric-lamas have no interest in them (Prophet, pp. 257-258).

This is typical Roerich - a master of creating the atmosphere in which one feels it improper to ask questions. But let us have a closer look at the above. Which book has "the lama" compiled - about Christ or about Chambhalla? Has Roerich actually seen that "darkest place" and "dusty corners"?

In another place (Prophet, 1984, pp. 276-277) we read: "Another source - historically less established - speaks also about the life of Jesus in Tibet...”. Again, any reader will ask what this "another source" is and in what way is it "historically less established" than some other, presumably more established one. The story that follows ${ }^{46}$ places Jesus in the temples of Lhassa ${ }^{47}$ in Tibet proper, wherefrom he travels to Leh, the capital of Ladakh, indicating that he had been to Tibet first. However, The Life of Saint Issa, chapter VI verses 2-6, says that he had been to Nepal and the Himalayas, but Lhasa is not mentioned, neither is Ladakh. We know that king Songtsen Gampo moved Tibet's capital to Lhasa in the middle of the VII century, but it is highly doubtful whether it was a city with established temples (of which religion?) at the time of Jesus.

On pp. 270-275 of Prophet 1984 we find a rich selection of stray verses from The Life of Saint Issa, but Roerich never says where he got them from. It is interesting that Yuri Roerich, Nicholas's son, a famous scholar in Tibetan studies who was the scientific leader of the Roerich expedition, never says even one word about those "documents

45 The legendary kingdom underneath the Himalayas, in whose existence Roerich deeply believed. The more popular spelling of its name is Shambhala, also used by Roerich in his other writings.

46 This story seems to be lifted straight from Levi (1908, chapter 36), allowing some small differences In wording.

47 Today universally spelt with a single "s". 
which have the antiquity of about 1500 years" ${ }^{\prime 8}$, even though he would be the one to translate them, as Nicholas Roerich did not know Tibetan.

The wording of the passages given by Roerich differs from the texts quoted by Notovitch and Abhedananda, though this may be at least partly attributed to different translations and translators. The texts quoted by Roerich are mostly isolated verses ${ }^{49}$ beginning with what corresponds to Notovitch and Abhedananda IV: 12-13, which means that Roerich's quotations begin exactly where Abhedananda's end.

Let us have a look at the only passage available in all the three versions, namely the concluding verses of chapter IV.

Notovitch 1894:

12/ Then it was that Issa left the parental house in secret, departed from Jerusalem, and with the merchants set out towards Sind,

13/ With the object of perfecting himself in the Divine Word and of studying the laws of the great Buddhas.

Abhedananda 1929 (?):

13/ At that time the desire was very strong in his mind to attain perfection through devotional service to God and that he should study religion with those who had attained enlightenment.

14/ He left Jerusalem, joined a group of traders, and set out for the land of Sind [the lower Indus valley, South Pakistan] ${ }^{50}$ where they used to purchase merchandise for export to various countries.

Roerich 1926:

12-13/ Isa secretly left his parents and together with the merchants of Jerusalem turned toward Ind to become perfected in the Divine Word. And for the study of the laws of the Great Buddha.

According to the text, this happened when Issa was 13 years old. Where and when had he come to know of Buddhism? None of the three versions says anything about it, as if Buddhism was something obvious in Jerusalem at the time of Jesus ${ }^{51}$. Moreover, Notovitch talks about "great Buddhas" which seems to hint at Mahayana, Roerich has one "Great Buddha", rather a Theravada wording, and Abhedananda only talks about "those who had attained enlightenment".

And let us repeat - at the very least, Notovitch and Abhedananda say they have seen the original text, but Roerich is silent about it.

48 As Trebst (2005, pp. 301-317) demonstrated, a number of passages quoted by Roerich may simply derive from Levi 1908. Let us remember that Roerich never says a word about his sources.

49 Some of them are continuous narratives, but with versification different from Notovitch. Prophet (1984) gives references to Notovitch for all the verses quoted by Roerich.

50 This indicates that the original text given by Prophet 1984 is the 1954 revised editi0n of Abhedananda's book, as in 1929 there was no Pakistan.

51 Gruber and Kersten (1994) argue convincingly that Buddhism was known in Judea and Qumran, but they focus on Buddhism, not on Jesus and his alleged travels to the East. 


\section{Elisabeth Caspari}

The basic text for this discussion is available in Prophet (1984, pp. 281-323).

The author closest to us in time, though probably the least known of the four, Elisabeth Caspari was born in Switzerland in 1899 and died in the US in 2002. As far as I know, no biography of hers seems to exist.

This time the story is rather brief. In 1939, during her trip to Ladakh, Mrs. Caspari and her friend Mrs. Gasque visited Hemis. The text does not say whether she had known Notovitch's or Roerich's books by that time ${ }^{52}$. She attended the Hemis Festival and stayed on for a few days. One day, in her own words:

(...) the librarian and two other monks approached the ladies carrying three objects. Madame Caspari recognized them as Buddhist books made of sheets of parchment sandwiched between two pieces of wood and wrapped in brocade - green and red and blue seeded with gold. With great reverence, the librarian unwrapped one of the books and presented the parchments to Mrs. Gasque: 'These books say your Jesus was here!'. One sentence (Prophet, 1984, p. 317).

Strangely enough, it seems the ladies did not ask the librarian for any details, having been satisfied with taking a picture of the monk holding the book. This picture is reproduced in Prophet 1984 on page facing page 313. This is the only "hard evidence" that such a book existed. However, the picture focuses on the monk, not on the book. What can be said about this mysterious book? It is definitely a Tibetan printed book, not too old (but this is my own impression, I do not claim to be right), but the text is wholly illegible, only the lines of writing and the margin lines are visible. As it is, it cannot be reconstructed.

But let us note another point. Notovitch spoke of two bound manuscript volumes; Abhedananda, of a manuscript; Roerich never says he had seen anything; finally, what Mrs. Caspari saw was quite definitely a Tibetan xylographic print, one of three volumes, while Notovitch claims to have seen two, and Abhedananda, one. I somehow cannot imagine that all the three have seen the same object.

So, if someone wants a proof that The Life of Saint Issa existed, or maybe still exists, all he has is an illegible photograph of an alleged one page of it. Whatever it is, it is definitely in Tibetan and is printed, not handwritten. Here the evidence of the Mysterious Book of Hemis comes to an end.

\section{Why such hoax?}

It is generally assumed that The Life of Saint Issa is a hoax. However, let us give some more attention to this point. If it is a hoax, and one that cost its perpetrator a court case and being sentenced to exile in Siberia ${ }^{53}$, would he benefit by it? Or would anybody else? We are moving on a slippery ground here, as we have, at best, only circumstantial evidence both for and against it.

\footnotetext{
52 Abhedananda's book was also already available, but it was in Bengali.

53 This is confirmed by Fader (2003, p. 182), quoting the original letter by Notovitch describing the trial and its outcome.
} 
Let us begin by quoting three statements by one who knew more about deducing solutions on the basis of circumstantial evidence than probably anyone else:

$1 /$ Circumstantial evidence is a very tricky thing. It may seem to point very straight to one thing, but if you shift your own point of view a little, you may find it pointing in an equally uncompromising manner to something entirely different.

2/ As a rule, the more bizarre a thing is, the less mysterious it proves to be.

3/ Problems may be solved in the study which have baffled all those who have sought a solution by the aid of their senses. To carry the art, however, to its highest pitch, it is necessary that the reasoner should be able to use all the facts which have come to his knowledge; and this in itself implies, as you will readily see, a possession of all knowledge, which, even in these days of free education and encyclopaedias, is a somewhat rare accomplishment (Doyle, 1982) ${ }^{54}$.

There are two attempts at answering our question in the literature available to me, one by Fader and one by Theroux. Both of them are against the story - Fader's favorite word is "fraud" appearing already in his book's title and repeated on almost every page, and Theroux says openly "I am firmly convinced that Notovitch was a liar" (Theroux, 2018). Their arguments follow different lines, but as we shall see, they share one important point.

Fader presents his views in the fourth chapter of his book that is titled The Cultural Climate That Gave Rise to the Notovitch Fraud (Fader, 2003, pp. 83-102). He points out that it was in the XIX century that rational Bible scholarship developed, Queen Victoria had herself crowned the Empress of India, and Helene Blavatsky's Theosophy made the Indian philosophy and religions household words in the West. Max Muller's monumental series Sacred Books of the East ${ }^{55}$ made all relevant sources available to whoever wanted to read them. The Indian origin of Christianity was either claimed or suggested by Louis Jacolliot (1837-1890) and Franciscus Joannes Maria Laouenan $(1822-1892)^{56}$. Notovitch was a Jew who converted to Russian Orthodox Church, so he had a good idea of the concepts of both religions, but not of Buddhism. Fader quotes the words of J. Archibald Douglas ${ }^{57}$ that Notovitch failed to understand Tibetan Buddhism. Fair enough - but completely off the track, as neither Tibet nor Tibetan Buddhism existed in the times of the alleged Saint Issa, and his story is set in India, not in Tibet. Fader stresses the Notovitch text places the blame for the death of Jesus on the Romans, not the Jews ${ }^{58}$, and suggests this may have been connected with the rise of antisemitism in Europe in the late XIX century. He attaches a lot of importance to Saint Issa's teaching on women ${ }^{59}$ and attributes it to the rise of women's movements in the late XIX-century Europe. Finally, he explains Notovitch's choice of Ladakh rather than

\footnotetext{
54 These are words of Sherlock Holmes taken from The Boscombe Valley Mystery, The Red-Headed League, and The Five Orange Pips respectively. All the three stories appear in Arthur Conan Doyle's The Adventures of Sherlock Holmes, first published in 1892.

55 Irreplacable until today, the only such collection in existence.

56 A less known name today, he was the bishop of Pondichery and wrote on Indian religious subjects in French.

57 A professor of history and English at Agra's Government College.

58 This argument is developed in chapters X through XIII of the Life of Saint Issa.

59 The Life of Saint Issa, chapter XII verses 8-21.
} 
Tibet proper as the place of his discovery in two ways: first, Ladakh in the Western opinion was a part of Tibet, and second, there were Christian missionaries in Ladakh who translated parts of the Bible into Tibetan and printed them, so this is what Notovitch might have come across ${ }^{60}$.

Both arguments do not stand to criticism. Ladakh was conquered by Kashmir in 1834 and incorporated into it in 1846 (Petech, 1977), so it was not a part of Tibet in 1887, though this may not have been widely known in Europe. True, the missionaries published and distributed parts of the Bible in Tibetan, but these are well-known and none of them answers Notovitch's description or Caspari's photograph.

Marcel Theroux's ideas take off from a point raised by Faber, namely the rising tide of antisemitism in late XIX century Europe. Theroux points out that during his long life in Paris Notovitch could not avoid at least some contact with Pyotr Rachkovsky (1853-1910) who was the chief of the notorious Okhrana or Russian secret police, based in Paris from 1885 until 1902. Rachkovsky is generally credited with either compiling or aiding the compilation of the text known as Protocoles of the Elders of Zion ${ }^{61}$. Theroux stresses (Theroux, 2018) that the assassination of Tsar Alexander II in 1881 gave rise to a violent wave of Russian antisemitism. Notovitch, as a converted Jew, knew the problem from his lifetime experiences. Could he hope that The Life of Saint Issa, which expressly states it was the Romans who are responsible for the death of Jesus, not the Jews who tried to defend him, might contribute to stop it or at least to placate it? As Theroux puts it, could it "vindicate the Jewish people of a charge that had dogged them for centuries"? (Theroux, 2018).

The trial of Notovitch may thus have had political undertones - the official policy of the Tsarist government was against the Jews, while Notovitch may have seemed to defend them by a book that set the Orthodox Church on the warpath. After all, the common reaction of all the established Christian churches to the books that claimed to fill some gaps in biblical narratives was pointing at Revelation 22: 18-19 taken as absolute proof there will be no more revelations.

If this guess is right, it adds tragic symbolism to what Theroux discovered - namely that Notovitch, a Russian Jew living in Paris, was arrested, deported to Auschwitz on $20^{\text {th }}$ December 1943, and gassed on $23^{\text {rd }}$ same month ${ }^{62}$.

Both Fader's and Theroux's views share one common point - the Life of Saint Issa, whatever else it was, has been produced to defend the discriminated weak, women, and the Jews. This goes far beyond the common connotations of the word "forgery".

60 The only Christian missionaries in Ladakh at the time of Notovitch were the Moravian Brothers. They published several translations of the Bible books and distributed them, but these are wellknown and none of them is printed in Tibetan xylographic way, so it cannot be the book seen in the Caspari photo. See Beszterda (2011) for a detailed study of the Moravian activities in Western Himalayas.

61 Available in Polish with a detailed introduction by Janusz Tazbir (1992).

62 See Theroux (2017, p. 360). Theroux's book is a novel, not an academic work, but he gives as his source the well-known work by Serge Klarsfeld - Memorial de la deportation des Juifs de France. I have no access to it. 


\section{The Muslim source on Jesus in India}

I think that most of the Western people do not know that Islam recognizes and accepts Christ, only saying he was not the last one sent by God to this world, the last one being the Prophet Muhammad. According to Islamic sources there are about 70 references to Prophet Jesus in the Holy Quran. ${ }^{63}$ There are many different traditions within Islam, but they all seem to agree that Jesus did not die on the cross. One of these traditions directly connects Jesus with India. It is the Ahmadiyya Islam.

The founder of the Ahmadiyya Movement was Mirza Ghulam Ahmad. He was born in Qadian, Punjab (today's India) in 1835 and died in Lahore (today's Pakistan) in 1908. He is frequently referred to as Qadiani Mirza. He proclaimed himself the Promised Messiah and Mahdi in 1889, thus launching what is now known as the Ahmadiyya Movement or Ahmadiyya Islam.

Of particular interest to us is Ghulam Ahmad's paper, or according to some, series of papers, published in 1899 in Urdu, collected into a book in Urdu in 1908, and translated into English either in the same year 1908 or in $1944^{64}$. The title of the book says it all: Maseeh Hindustan Mein, Messiah in Hindustan. This is available in English as Jesus in India ${ }^{65}$.

The main thesis put up by Ghulam Ahmad is that Jesus did not die on the cross, but survived and travelled to Kashmir, where he lived for many years in today's village of Rozabal near Srinagar, where his and his mother's tombs survive until today. This story has a substantial body of literature for and against it, but it cannot be discussed here for reasons of space and unavailability of sources.

\section{Later Western sources in chronological order}

Before I begin, I want to make it clear that I regard the channeled works as sources in their own right. As those who channeled them lived in different times and places, and did not know each other or of each other, it is difficult to think they all formed a conspiracy of hoaxers.

1882 - OAHSPE, frequently though incorrectly called the OAHSPE Bible. An extremely interesting work channeled through Dr. John Ballou Newbrough (1828-1891), covering the spiritual history of Egypt, Persia, India, China and the North American Indians. The second edition, slightly revised, came out in 1891. OAHSPE contains an alternative account of Jesus - called Joshu in the text - but does not say he travelled to India.

1898 - The Gospel of the Holy Twelve, attributed to Gideon Jasper Ouseley (18351906), serialized 1898-1901, book edition 1901. This text, claimed to be a translation

\footnotetext{
${ }^{63}$ Jesus in the Quran. Islami City, https://www.islamicity.org/6405/jesus-in-the-quran (access 10.08.2018).

64 Different sources do not always say what the language of the 1908 edition was, and I have seen references specifying the year 1944 as the one of the English translation.

65 The copy I have was published by Islam International Publications Limited, Tilford, Surrey, UK 1989, a reprint of the original 1944 edition.
} 
of an Aramaeic manuscript found in Tibet, contains the following remark in its Lection VI, verse 16:

And after a time he went into Assyria and India and into Persia and into the land of the Chaldaeans. And he visited their temples and conversed with their priests, and their wise men for many years, doing many wonderful works, healing the sick as he passed through their countries.

The text suggests this took place in the $32^{\text {nd }}$ year of his life.

1908 - The Aquarian Gospel of Jesus the Christ by Levi (= Levi H. Dowling, 18441911). The author claimed his work to be derived from akashic records ${ }^{66}$, which indicates his knowledge of Theosophy. This book contains very detailed descriptions of Jesus's life and works in India (Section VI), Tibet and Western India (Section VII), Persia (Section VIII), Assyria (Section IX), Greece (Section X), and his work in the Council of the Seven Sages of the World (Section XII). The stories narrated in this text parallel many episodes found in Notovitch's Life of Saint Issa, as well as in Roerich's Himalaya.

1955 - The Urantia Book. Usually described as the longest channeled text to date - it is a volume of 2100 pages - this astonishing work divides into four parts with consecutive numbering of chapters, called "Papers" in the text. The fourth and last part of the Urantia Book is titled "The Life and Teachings of Jesus" and covers Papers 120-196 (pp. 1323-2097). Of special interest are Papers 94, 95, and 131, which contain a lot of information about the non-Christian religions. Paper 131 is claimed to contain notes that Jesus and his friend Ganid, son of a rich Indian merchant Gonod, took in the Alexandrian library, where they studied works on different religions. These contain an incredible mix of facts and pure nonsense. I leave their discussion for the second part of this paper, now in preparation. Let us only add that in paper 130 we read about Jesus meeting - at Caesarea - a Mongolian traveler speaking fluent Greek, a Taoist, with whom Jesus has a long conversation. Though different parts of the Urantia Book pay a lot of attention to India, Indian religions and Indian philosophy, the text does not say anything about Jesus travelling there.

1994 - The Kolbrin. A very little-known book which connects three worlds: Egyptian, Israeli, and Celtic. The second edition of it came out in 2008, both in New Zealand. An American edition, titled The Kolbrin Bible $e^{67}$ and claimed to be unauthorized - but useful because of its index and verse numbering - was published in 2005. The Kolbrin's last part, titled the Britain Book, Chapters Two and Three, contains an account of Jesus but is silent about his alleged travel to India.

1998 - The Gospel of the Kailedy, described as the second part of The Kolbrin. It is the life of Jesus, full of interesting details but silent on India, though it contains a Bud-

66 The Akasha or Akashic Records is a concept similar to Buddhist alaya-vijnyana, Jung's universal consciousness or Sheldrake's morphogenetic field. It is described as the subtle-matter plane of existence that records the vibrations of all events taking place on Earth. Some psychics claim to be able to connect to it and see - if this is the right word - events from the past recorded in it. Rudolf Steiner (1861-1925), the founder of Anthroposophy, claimed to have derived much of his knowledge from those records. The word akasha is frequently translated as "ether", as the Indian philosophy describes it as the fifth of the traditional elements (water, fire, earth, air).

${ }^{67}$ The original edition is titled just The Kolbrin. Let us remember that the name "Bible" was also added to the title OAHSPE. 
dhist parable that it attributes to Jesus ${ }^{68}$. As The Kolbrin, this book also makes the Jesus-Celtic connection.

2003 - Das ist Mein Wort. Alpha und Omega. Das Evangelium Jesu. Die ChristusOffenbarung, welche inzwischen die wahren Christen in aller Welt kennen. This amazing work is not yet available in English. It is channeled through a contemporary mystic known as Gabriele of Wurzburg. This book is based on the text given by Ouseley in 1898-1901; it is presented as a commentary on selected passages from it given by Jesus himself. Commenting upon the passage I quoted in describing Ouseley's work (section XII above), Jesus says:

As Jesus I met many people from various social strata, speaking different languages. I talked with
the Assyrians, the Hindus, the Persians, the Chaldaeans, the Israelites and many more men and
women from various nations. But I never travelled to their countries, nor to any other ones, to
learn God's wisdom. I travelled across many countries and I have crossed many a frontier. Lan-
guage was frequently an obstacle, However, when we talk about the laws of love, everyone knew,
what his fellow man wanted to say. The speech of the heart knows no frontiers - also today, in
times when the year 2000 is approaching ${ }^{69}$.

I must say that both this book, and some other ones coming from Gabriele that I have been fortunate to get and study, are so full of astonishing insights and wisdom that I can only bow my head to Gabriele. I know many of my readers will tend to laugh at it. Let them.

So, we could say the question is solved - Jesus himself says he has not travelled anywhere "in search of God's wisdom", that is "to learn", though He did travel a lot.

However, the question remains: even if The Life of Saint Issa existed only in Notovitch's imagination in 1887, what did Abhedananda see in Hemis in 1922, and what did Mrs. Caspari see and photograph there in 1939? For it is obvious they saw something.

Scio me nihil scire

\section{Acknowledgements}

My first words of thanks go to the memory of Elizabeth Clare Prophet to whom this paper is dedicated. Without her work it would be very difficult to get access to the most important accounts of the Mysterious Book of Hemis.

I am grateful to Peter Duffy, Spiritual Director of The Summit Lighthouse, for his permission to reproduce the Caspari photograph, the only extant evidence that The Life of Saint Issa did exist.

My thanks go to the late Ursula Eichstaedt, once known all over North India as Sister Ursula, who invited me to join her in her trip across Ladakh in 1976, which included long stays both at Hemis and in Rozabal. She had been to Ladakh many times before and showed me things I would never come to know otherwise.

\footnotetext{
${ }^{68}$ The paraphrase of the story of the monk who wanted to play lute, see The Gospel of the Kailedy, p. 42.

69 Quoted after the Polish edition - ISBN 83-911929-6-2, no place, no date, p. 88.
} 
I am grateful to H. Louis Fader and Hans-Jürgen Trebst, both of whom honoured me with their books at different times. Having both before me makes me understand the wise words of the Buddha on the necessity of navigating between extremes!

I acknowledge my gratitude to Guy Penman and The London Library for their invaluable help in assembling the list of Notovitch's published works.

I am grateful to Ms. Leslee Alexander for gift copies of OAHSPE, The Urantia Book, Jon Klim o's Channeling, and priceless help in my studies by answering dozens of questions; to Laraine Coley for copies of The Kolbrin and The Gospel of the Kailedy; to Serge and Cynthia Bison for a copy of Clyde Bedell's Concordex of the Urantia Book; to Karen Le Beau for a copy of her unpublished paper of 1988; and to my friend the Rev. Bent Reidar Eriksen for a copy of Romarheim's book in Norwegian. Finally, I thank my friend Rafał Beszterda for a copy of Ahmed Shah's chapter on Notovitch, a rare book I myself have never seen.

\section{Appendix I}

A list of Notovitch's writings (probably incomplete)

Following the lead given by Marcel Theroux, with the invaluable help of Mr. Guy Penman and the London Library, I obtained a list of Notovitch's writings. This completes both my own researches and Andreyev's (2009). I could not locate the date of publication of a few titles. The list, in chronological order, is given below. It does not claim to be complete. However, until now Notovitch has chiefly been remembered as the author of one book, while we see that his works are many and varied. Today he would probably be classified as a historian and political scientist first, a poet, playwright and cultural anthropologist second. The Unknown Life of Jesus seems to be an exception in his literary output, not a typical book of his. His French publisher was usually Paul Ollendorf, Paris.

1880 - Patriotizm. Stikhotvoreniia [Patriotism. Poems]. In Russian.

1882 - Zhizneopisanie slavnogo russkogo geroia i polkovodtsa generale - adiufanta, generale infanterii M. D. Skobeleva [The Life of the Famous Russian Hero and Military Leader, the General of Infantry M. D. Skobelev ${ }^{70}$. In Russian.

1888 - Kvetta i voennaia zheleznaia doroga cherez pereval Bolan i Gernai [Quwetta and the wartime military railway line across the Bolan and Harnai Passes]. In Russian.

1889 - Pravda o evreiakh [The truth about the Jews]. In Russian.

1890 - L'Europe a la veille de la guerre.

1893 - L'Eempereur Alexandre III et son entourage.

1893 - Le Tsar, son armee at sa flotte.

1894? - Alexander III und seine Umgebung. The German translation of the 1893 monograph.

\footnotetext{
70 Mikhail Dimitryeyevich Skobelev (1843-1882), was one of the most famous Russian generals of the XIX century, the hero of Russia's war with Turkey in 1877-1878, and the conqueror of large parts of Central Asia that became parts of the Russian Empire.
} 
1894 - Souvenirs de Sebastopol, written by the Tsar Alexander III, translated into French by Notovitch.

1894 - La vie inconnue de Jesus Christ, first edition, in French.

1895 - The Unknown Life of Jesus Christ, first English edition, London.

1895? - The Unknown Life of Jesus Christ, first American edition, New York.

1895 - L'Empereur Nicolas II et la politique russe.

1898 - L'Europe et l'Egypte.

1899 - La pacification de l'Europe et Nicolas II.

1900 - La vie inconnue de Jesus Christ, second enlarged edition. In French.

1906 - Le Russie et l'alliance Anglaise, etude historique et politique.

NB - according to Marcel Theroux (2018), a copy of this volume belonging to the London Library has a lengthy inscription to the Duchess of Kent signed "Nicholas Notovitch, January 1939", a proof he was still alive that year.

1907 - Rossia i Anglia, istoricheskii i politicheskii etud [Russia and England, a historical and political study]. In Russian.

1909 - second edition of the previous title.

1910 (?) - the Russian translation of La vie inconnue de Jesus Christ.

1916 - A vida desconhencida de Jesus-Christ. In: Ensaios de historia e critica, edited by Jorge Araujo and Arthur de Guimaraes, Rio de Janeiro 1969, pp. 197-221. In Portugese.

? - La livre d'Or.

? - Marrage ideal, drame in 4 actes.

Works announced as "To appear soon" in 1906:

Gallia - drame historique, prologue et 4 tableaux.

La travers de Perse, relation de voyage illustree.

La Femme a travers le monde, etudes, observations et aphorismes.

La travers l'Inde.

\section{Appendix II}

\section{The basic reading list}

The literature on the myth of Jesus in India is immense, in many languages, and largely repetitive. Virtually each book listed below refers to many others, most of them beyond my reach. As I can only list the books I have before me, I prefer not to call it bibliography.

\section{The basic source}

Prophet, E. C. (1984). The Lost Years of Jesus. On the Discoveries of Notovitch, Abhednanda, Roerich, and Caspari. Malibu: Summit University Press ${ }^{71}$.

71 The indispensable one-volume edition of the four basic sources with an excellent introduction and footnotes. Includes a complete text of the first English edition of Notovitch's book. 


\section{Channeled texts referred to in the paper}

Bedell, C. (1991). Concordex of the Urantia Book. New enlarged $3^{\text {rd }}$ edition. Santa Barbara (California): Clyde Bedell Estate ${ }^{72}$.

Dowling, L. (1919). The Aquarian Gospel of Jesus the Christ. Los Angeles: [s.n.] $]^{73}$

Ewangelia Życia Doskonałego: Piąta Ewangelia (2004). The Polish translation of the previous item by the Rev. Henryk Zalewski. Warszawa: Ludowa Spółdzielnia Wydawnicza ${ }^{74}$.

Gabriele (2003). Das ist Mein Wort. Alfa und Omega. Das Evangelium Jesu. Die Christus-Offenbarung, welche inzwischen die wahren Christen in aller Welt kennen. Marktheidenfeld; Altfeld: Verlag Das Wort $\mathrm{GmbH}^{75}$.

Gabriele (2003). To jest Moje Słowo. Alfa i Omega. Ewangelia Jezusa. Objawienie Chrystusowe jakie znaja już prawdziwi chrześcijanie na całym świecie. Warszawa: Stowarzyszenie dla Popierania Życia Uniwersalnego ${ }^{76}$.

Ksiega Urantii (2016). The Polish translation of the Urantia Book by Małgorzata and Przemysław Jaworscy. Chicago: The Urantia Foundation ${ }^{77}$.

Ouseley, G. J. Rev. (s.a.). The Gospel of the Holy Twelve. [S.l.]: Dodo Press Reprint ${ }^{78}$. Newbrough, John Ballou (1882). OAHSPE: A New Bible. First edition. New York: Newbrough ${ }^{79}$.

Sadler, W. S. (1955). The Urantia Book. First edition. Chicago: The Urantia Foundation $^{80}$.

The Gospel of the Kailedy (1998). Coromandel (New Zealand): The Culdian Trust ${ }^{81}$.

The Kolbrin (1994). Coromandel (New Zealand): Published by The Culdian Trust under license from The Hope Trust ${ }^{82}$.

The Kolbrin Bible (2006). Edited by Janice Manning (Editor) and Marshall Masters (Contributor), NV (USA): Your Own World Books, Silver Springs ${ }^{83}$.

\footnotetext{
72 The invaluable Urantia Book study aid combining the features of an index and a concordance. A monument to Clyde Bedell's scholarship. ISBN 0-916014-75-4.

73 An undated reprint of the edition published and for sale by Eva S. Dowling. ISBN 1-59462-321-X.

74 Supplementary volume: (2005). Warszawa: Dom Księgarski "Ezoteric".

75 German original's ISBN 9787-3-89201-960-2.

76 This monumental work is essentially a channeled commentary on The Gospel of the Holy Twelve (see II.2. above), attributed to Jesus Himself. Polish translation ISBN 83-911929-6-2.

77 ISBN 978-1-883395-07-0.

78 ISBN 1-905432-24-0.

79 Reprinted by Ray Palmer in Amhest, Wisconsin, in 1960, reissued in 1970 and 1972. The last edition, known as the Green OAHSPE, contains the original Commentary, Newbrough's portraits of the world's religious leaders, the important Book of Discipline, and a very good index. This is the most authoritative edition of the text whose title is usually capitalized as OAHSPE, sometimes called OAHSPE Bible.

80 Oft cover second printing 1995. ISBN 0-911560-50-5.

81 The second part of The Kolbrin.

82 Second edition 1998. ISBN 0-9583313-3.

83 This edition features a handy citation system and a good index. The word "Bible" has been added to the original title by the editors. ISBN 13:978-1-59772-005-2.
} 


\section{Other books and papers consulted}

Amore, R. C. (1978). Two Masters, One Message. Nashville: Abingdon Press.

Andreyev, A. (2009). Russian travelers in Ladakh. Ladakh Studies. Vol. 24 (June), pp. 25-41.

Beszterda, R. (2011). Bracia morawscy a kultury himalajskie [The Moravian Brothers and Himalayan Cultures]. Prace Etnologiczne. Vol. 24. (Wrocław; Warszawa: Polskie Towarzystwo Ludoznawcze $)^{84}$.

Däniken, E. von (1994). Śladami wszechmogacych [Auf dem Spuren der Allmächtigen]. The Polish translation by Andrzej Dworak. Warszawa: Świat Książki.

Faber-Kaiser, A. (1977). Jesus Died in Kashmir. London: Abacus, Sphere Books.

Fader, H. L. (2003). The Issa Tale That Will Not Die. Nicholas Notovitch and His Fraudulent Gospel. Lanham; Boulder; New York; Toronto; Oxford: University Press of America ${ }^{85}$.

Gdok-Klafkowska, M. (2013). Some Remarks on the Works of the Roerich Family Showing the Himalayan World. Zwierciadło Etnologiczne: Rocznik Katedry Etnologii i Antropologii Kulturowej Uniwersytetu Szczecinskiego. Vol. 2, pp. 9-19.

Gdok-Klafkowska, M. (2011). The Dream of Kanchenjonga: The Roerich Family and Himalayan Studies. In: McKay Alex, and Balikci-Denjongpa, Anna (ed.). Buddhist Himalaya: Studies in Religion, History and Culture. Vol. 1: Tibet and the Himalaya. (Sikkim) Gangtok: Namgyal Institute of Tibetology, pp. 305-32286.

Grönbold, G. (1985). Jesus in Indien. Das Ende einer Legende. München: Kösel Verlag.

Gruber, E. A., and H. Kersten (1996). Pra-Jezus. Buddyjskie źródła chrześcijaństwa [Der Ur-Jesus. Die buddhistischen Quellen des Christentums]. The Polish translation by Mieczysław Dutkiewicz. Gdynia: Uraeus.

Hassnain, F. M. (1998). Poszukujac prawdziwego Jezusa [A Search for the Historical Jesus]. The Polish translation by Sławomir Studniarz. Bydgoszcz: Limbus.

Hazrat Mirza Ghulam Ahmad of Qadian (1989). Jesus in India. Tilford (Surrey, UK): Islam International Publications Limited.

Kersten, H. (s.a.). Jezus żył $w$ Indii [Jesus lebte in India]. The Polish translation. [S.1.: s.n.].

Klafkowski, P. (s.a.). The Roerich Family and Ladakh. To appear in the volume of proceedings of the $18^{\text {th }}$ Colloquium of the International Association of Ladakh Studies held in Będlewo, Poland, on May 2-6, 2017.

Klimo, J. (1998). Channeling. Investigations on Receiving Information from Paranormal Sources. Revised and enlarged. Berkeley (California): North Atlantic Books ${ }^{87}$.

Korabiewicz, W. (1992). Tajemnica młodości i śmierci Jezusa [The Mystery of the Youth and Death of Jesus]. Warszawa: Wydawnictwo Przedświt.

\footnotetext{
84 In Polish, an excellent study of the cultural influence of the Moravians on the peoples they worked with. Contains a lot of information on their Bible translations.

85 Contains much material not available elsewhere.

86 Contains biographic information on the Roerich Family, an extensive annotated bibliography of recent Roerich studies in Russian, and an outline of the Roerichs' Sikkim connections.

87 The monumental work that made its subject "legitimate" to official science.
} 
Landman, S. (2001). Jezus w Kaszmirze? [Jesus starb nicht in Kaschmir. Ohne Kreuzestod kein Christentum]. The Polish translation by Antoni Baniukiewicz. Gdynia: Uraeus.

LeBeau, K. (s.a.). Buddhist Influence on the Teachings of Jesus Christ: The Lost Years of the Master of Galilee. Unpublished paper of 1988 received from the author.

Le Maulana, J. D. Shams (1986). Oú mourut Jesus? Londres: Al-Shirkat al-Islamiyyah.

Meyer, M. W. (1984). The Secret Teachings of Jesus: Four Gnostic Gospels. New York: Vintage Books.

Müller, M. (1894). Some articles on Notovitch, the Unknown Life of Christ. The Nineteenth Century. Vol. 36 (July-December), pp. 515-522. Available on the web: http://www.tertullian.org/rpearse/scanned/notovitch.htm (access 20.04.18).

Nakamura, H. (1986). Buddhism in Comparative Light. Second revised edition. Delhi; Varanasi; Patna; Madras: Motilal Banarsidass.

Petech, L. (1977). The Kingdom of Ladakh c. 950-1841 A. D. Serie Orientale Roma. Vol. 51. Rome: Istituto italiano per il Medio ed Estremo Oriente.

Potter, C. F. (1958). The Lost Years of Jesus Revealed. From the Dead Sea Scrolls and the Nag-Hammadi discoveries. New York: Fawcett Gold Medal Books ${ }^{88}$.

Prophet, M. L., and E. C. Prophet (1986). The Lost Teachings of Jesus. Two volumes. Livingston MT: Summit University Press.

Romarheim, A. (1988). Kristus $i$ Vannmannens Tegn: Nyreligiose oppfatningar av Jezus Kristus. Oslo: Credo Forlag ${ }^{89}$.

Rommarheim, A. (s.a.). Various views of Jesus Christ in new religious movements a typological outline. Available on the web under the author's name and the title (access 5.4.2018) ${ }^{90}$.

Shah, A. (1906). Four Years in Tibet. By Rev. Ahmad Shah. Benares: E. J. Lazarus \& Co.; Allahabad: Printed at the Medical Hall Press Branch.

Tazbir, J. (1992). Protokoły Mędrców Syjonu: autentyk czy falsyfikat. Warszawa: Interlibro ${ }^{91}$.

Theroux, M. (2017). The Secret Books. London: Faber and Faber ${ }^{92}$.

Theroux, M. (s.a.). Did Jesus spend his missing years studying Buddhism in India? Marcel Theroux visits Ladakh to find out. The Telegraph. Available on the web: https://www.telegraph.co.uk/travel/destinatioins/asia/india/articles/Ladakh-and-theunknown-life-of-jesus-christ (access 5.5.2018).

Theroux, M. (2018). The post-truth Gospel. Times Literary Supplement of January 9. Available on the web: https://www.the-tls.co.uk/articles/public/the-post-truthgospel/ (access 5.5.2018).

\footnotetext{
88 Reprinted by Ballantine Books in 1982.

89 Contains excellent bibliography.

90 Essentially a detailed summary of the Norwegian book.

91 The reprint of the 1938 Polish edition of the Protocoles of the Elders of Zion with a detailed introduction by one of Poland's most eminent historians.

92 Well-researched biographical novel on the life of Notovitch, unfortunately without notes.
} 
Trebst, H.-J. (1988). The Quest for the Issa Manuscripts at Hemis. Paper presented at the International Association of Ladakh Studies Conference at Leh, August 1988. Typescript received from the author.

Trebst, H.-J. (2005). Jesu verborgene Jahre. War er in Indien? Cornelia Goethe Akademie für literarisches Schreiben (Frankfurt/Main) ${ }^{93}$.

93 Contains parallel comparisons of Notovitch's text with The Aquarian Gospel of Jesus the Christ and an excellent bibliography. 